\title{
Integrating Plant Trials into Teaching and Student Research
} Programs

\author{
Michael A. Arnold, ${ }^{1}$ R. Daniel Lineberger, ${ }^{2}$ Tim D. Davis, ${ }^{3}$ Steven W. George, ${ }^{4}$ Wayne A. Mackay, ${ }^{5}$ \\ Greg D. Grant, ${ }^{6}$ Jerry M. Parsons, ${ }^{7}$ and Larry A. Stein ${ }^{8}$
}

AdDitional INDEX wORDs. teaching methodology, undergraduate and graduate instruction, public gardens, CEMAP

Summary. Plant trialing and marketing assistance programs have become popular in recent years with several state and some regional programs emerging. Successful implementation requires considerable labor, facilities, and monetary resources for evaluation of large numbers of taxa over several years to ensure that plants are well adapted to the region of interest. Research and development funds, dedicated facilities, and cooperator commitment to trialing programs can be limiting during the early years of the programs. Involvement in plant trialing programs allows students to be exposed to plot layout planning, statistical design, plant maintenance, data collection and analysis, and professional communication of trial results. Construction of facilities for conducting plant trials, growing plants for use in trials, trial installation, and maintenance of plants all provide practical hands-on horticultural training. Replicated plant trials provide the latest information on regionally adapted taxa for inclusion in classroom instruction and publications. Plant trialing programs benefit from labor assistance, development of dedicated facilities, and the opportunity to share equipment and supplies among teaching, trialing, and student research projects.

$\mathrm{V}$ arious states have developed plant trialing and marketing assistance or consumer education programs to promote the use of locally adapted landscape plants (Arnold et al., 1998a, 1998b; Mackay et al., 2000). Regional plant trialing programs, such as the South Extension Research Activity Information Exchange Group-27, have emerged to provide wider based regional recommendations. State programs vary from simple selection committees to multi-year, multilocation field trialing and selection.

\footnotetext{
Experiments were funded by the Texas Agricultural Experiment Station, Texas A\&M University, Texas Ornamentals Enhancement Endowment, and Texas A\&M University Faculty Minigrant Program. Mention of a trademark, proprietary product, or vendor does not constitute a guarantee or warranty of the product by the authors, the Texas A\&M University or Texas Agricultural Experiment Station, and does not imply its approval to the exclusion of other products or vendors that also may be suitable. The cost of publishing this paper was defrayed in part by the payment of page charges. Under postal regulations, this paper therefore must be hereby marked advertisement solely to indicate this fact.

${ }^{1}$ Associate professor, Texas A\&M University, Department of Horticultural Sciences, College Station, TX 77843-2133.

${ }^{2}$ Professor, Texas A\&M University, Department of Horticultural Sciences, College Station, TX 77843-2133.

${ }^{3}$ Professor and resident director, Texas A\&M University Research and Extension Center-Dallas, 17360 Coit Rd., Dallas, TX $75252-$ 6599

${ }^{4}$ Associate professor, Texas A\&M University Research and Extension Center-Dallas, 17360 Coit Rd., Dallas, TX $75252-6599$

${ }^{5}$ Associate professor, Texas A\&M University Research and Extension Center-Dallas, 17360 Coit Rd., Dallas, TX $75252-6599$

${ }^{6}$ Lecturer, Stephen F. Austin State University, Box 13000, Stephen F. Austin Station, Nacogdoches, TX 75962-3000.

${ }^{7}$ Professor, Texas Agricultural Extension Service, 3427 Northeast Parkway, San Antonio, TX 78218.

${ }^{8}$ Professor, Texas A\&M University Research and Extension Center-Uvalde, 1619 Garner Field Rd., Uvalde, TX $78802-1849$.
} 
Some are run independently by industry trade organizations or university personnel, others are joint efforts between university and industry. Cooperative ventures provide a framework to capitalize on the research and communication skills of university personnel and the marketing expertise present in industry organizations.

While many attributes are common to most trialing programs, the mechanisms for acquiring the necessary resources and expertise to run the trials vary among test sites. As programs mature, sources of recurring funding should be located more readily. However, during early stages of the program, industry may be reluctant to provide continuous funding as tangible results can require several years to produce. Integration of plant trialing activities into existing or new undergraduate and graduate courses and research programs provides an innovative way to enhance student educational experiences while accomplishing the applied research necessary for plant trialing programs. The objective of this paper is to describe mechanisms for incorporating plant trialing activities into undergraduate and graduate teaching and research programs and to describe some of the benefits to the various participants as a result of these activities.

\section{Graduate thesis- dissertation work}

Graduate student instruction/advisement consumes significant portions of faculty time and is very individualized. Most graduate projects are flexible enough to answer many prerequisite questions about the production and marketing of potential promotional plants if they are planned well in advance. Certainly those faculty with breeding programs can easily involve students directly in genetic manipulation and selection activities related to the trialing programs.

For those faculty whose plant trialing programs are not the principal focus of their research programs, graduate student participation may require more innovative strategies. Conventional propagation and tissue culture projects can be tailored to aid in elucidating propagation methods for promising taxa. Likewise, field or production oriented projects can be used to refine production methods for promising plants. Inclusion of these taxa as test subjects for substrate, fertility, growth regulator, or pesticide-oriented studies can be a useful tool for screening various taxa's adaptability to conventional production systems. For instance, one of our graduate students working on a substrate project concerning fertility interactions with kenaf stalk core and coconut coir dust was able to incorporate screening of several promising small tree species for their compatibility with conventional container production practices (Arnold et al., 1996; Goyne, 1998). Serendipitously, this work also yielded three thornless clones of wright acacia (Acacia wrightii Bentham and Gray) which are subjects of a propagation project for another student's masters work and will eventually be funneled into the CEMAP trialing program. The College Station, Texas, trial location serves as one of the primary screening sites. Additional preliminary screening may occur at selected locations around the state. Once a plant is deemed promising, adequate numbers of plants are provided by the sponsoring cooperator to include the plant in the statewide trials. The organizational cess is described in the accompanying article in this symposium by Mackay et al. (2001).

Similarly, a supplementary research project conducted by a $\mathrm{PhD}$ student studying a new container production system allowed the screening of a number of lacebark elm (Ulmus parvifolia von Jacquin) seedlings from a mature tree with red autumn fruit and attractive bark (Arnold and McDonald, 1999). Fortunately, some of these seedlings exhibited weeping forms, with one yet to be named clone having a pronounced weeping habit structure and a flow chart of the pro-

reminiscent of weeping yaupon (Ilex vomitoria Ait. 'Pendula'). Determining propagation requirements of this plant is a portion of yet another masters project. Propagation projects are particularly germane to plant trialing programs because plants must be reliably produced in large quantities to satisfy the consumer demand created by successful educational and marketing efforts.

\section{Special problem-research courses}

Another opportunity to integrate the research and teaching programs into plant trialing is the judicious designing of undergraduate or graduate special problems or research courses. Undergraduate research projects can easily include comparisons of a number of related taxa for growth habit, flowering, and disease or pest resistance. For example, we had an undergraduate student project that involved direct data collection from the perennial verbena (Verbena L.), lantana (Lantana L.), and salvia or sage (Salvia L.) taxa in the 1996 CEMAP trials. An alternative to direct student assistance with the official statewide trials is to supervise students in the preliminary screening of large numbers of taxa within a particular species or genus to gauge the range of landscape responses for potential inclusion in formal state or regional trials. For example, one of our undergraduate students evaluated the disease and heat resistance of various species and cultivars of zinnia ( $\mathrm{Zin}$ nia L.) (Morgan et al., 2000). Data from this study have pared the number of taxa to be evaluated in the full 20 location statewide trials to a more manageable five or six cultivars.

Advanced undergraduate or

Table 1. Direct involvement ${ }^{\mathrm{z}}$ of undergraduate students in lecture or laboratory activities related to the plant trialing programs at the College Station, Texas, Coordinated Education and Marketing Assistance Program trialing site from June 1999 through May 2000.

\begin{tabular}{lcr} 
Course title & Semester & Enrollment \\
\hline Directed studies in horticulture & Summer 1999 & 7 \\
Landscape maintenance and construction & Fall 1999 & 26 \\
Directed studies in horticulture & Fall 1999 & 3 \\
Greenhouse management & Fall 1999 & 15 \\
Nursery management & Fall 1999 & 19 \\
Directed studies in horticulture & Spring 2000 & 1 \\
Landscape plant materials & Spring 2000 & 90
\end{tabular}

${ }^{\mathrm{z}}$ Direct involvement included at least one laboratory or lecture session held at the trialing site. Most courses involved multiple use dates. 
graduate research projects may lend themselves to investigation of specific plant responses at a more fundamental level. Another of the small trees initially included in Goyne et al.'s work (Goyne et al., 1997, 1998) was promising, but propagation procedures for american smoke tree (Cotinus obovatus Raf.) were poorly defined. This led to an undergraduate honors project that investigated the effects of auxin concentration, cutting maturation, and substrate composition on rooting of american smoke tree that was the winner of the 2000 Southern Region ASHS undergraduate paper competition (Denny and Arnold, 2000).

Similar projects can be used to enrich the teaching program through the learning of research methodology and honing of presentation skills at industry and scientific meetings (Denny and Arnold, 2000; Morgan et al., 2000). Development of technical writing skills can be enhanced by publishing manuscripts in refereed journals (Arnold and McDonald, 1999), trade journal updates (Arnold et al., 1996; Goyne et al., 1997), or extension publications. If conducted in a replicated fashion, landscape trial results may be published in peer reviewed journals, such as HortTechnology, which has a specific section for reporting plant trials. This satisfies several needs: 1 ) that faculty publish refereed articles, 2) that students learn to quantify ornamental plant performance which has historically been rather subjective, and 3 ) that plant evaluations be verified by subjecting them to peer review. Such projects can also serve as a vehicle for exposing students to interdisciplinary efforts with other fields such as biology, botany, genetics, plant pathology, entomology, and agricultural economics. Morgan's project (Morgan et al., 2000), where she learned to identify and score pathogens of zinnia from our extension plant pathologist (Larry Barnes, Texas A\&M University, Dept. Plant Pathology and Microbiology), was a good example of exposure to interdisciplinary work.

\section{Enhanced classroom and laboratory instruction}

Plant trials can serve as a source of valuable information for landscape plant materials and landscape design courses. Over time, results of these experiments can be incorporated into lecture content, laboratory activities, textbooks, course packets, or Internet materials developed for use in these courses (Arnold, 1999; Lineberger and Arnold, 2001). These publications can double as mechanisms for distributing long-term results to industry personnel and the general public. Use of trial results showing performance differences in various areas of the state or region, or in different cultural regimes, provides excellent illustrations of genotype by environment interactions. Such applied, discipline-relevant examples are more readily conveyed to nonbiological science majors, such as landscape architecture and urban planning students, than those from conventional genetic studies with model systems such as fruit flies (Drosophila melanogaster Meigen).

Laboratory exercises can provide labor for plant trialing programs by growing plants for trials as laboratory projects for nursery management and greenhouse production courses. Laboratories for landscape maintenance or public garden management courses can assist with maintenance of trial plantings. Such strategies have been shown to be successful in providing maintenance assistance in public garden settings, while adding to the hands-on experiences in a variety of landscape related courses (Hamilton, 1999; Lewis and Affolter, 1999; Stimart, 1999; VanDeranden and Cook, 1999). During the past year alone, 161 undergraduate students have benefited from direct classroom or laboratory contact with the plant trials at our College Station location (Table 1). Students from other disciplines at Texas A\&M University, Botany and Entomology, and sister institutions, such as Stephen F. Austin State University, were also involved indirectly in field trips to visit the site.

\section{Facilities development}

Dedicated facilities for conducting replicated landscape trials where plant trials must be conducted in raised beds or when demonstration landscape plantings are required are expensive. Construction of demonstration landscape settings and trial beds make excellent laboratory activities in landscape construction courses or subjects for advanced special problems courses. Student participation at the Texas A\&M University Nursery/Floral Field Laboratory has resulted in the construction of more than $325 \mathrm{~m}^{2}(3,500$ $\left.\mathrm{ft}^{2}\right)$ of raised bed trial space and about 2 ha ( 5 acres) of demonstration gardens. The demonstration gardens and landscape trial beds were officially recognized in Summer 2000 as the Texas A\&M University Horticultural Gardens bringing additional public and institutional recognition to the trialing programs. Similar strategies have been shown to work in various public gardens (Hamilton, 1999; VanDerZanden and Cook, 1999).

\section{Conclusions}

One of the common criticisms by our industry is that horticulture departments do not do a good job when preparing students for "real world" experiences. Many of the suggestions/ examples in this paper help address this criticism, while at the same time teach students to better understand the academic pursuits of research and service. Landscape plant trialing programs offer outstanding opportunities for development of undergraduate and graduate research projects. These projects provide students opportunities to learn and apply research methodology to specific industry related problems. Undergraduate student involvement in activities that directly or indirectly support CEMAP plant trialing on the Texas A\&M University campus have allowed us to test many more taxa than we could have if inkind services by students would have been contracted for pay. Undergraduate teaching programs have been enhanced by direct replicated comparisons of various taxa and an expanded variety of taxa available for inclusion in plant materials courses. Landscape construction, landscape maintenance, and design courses have benefited from the availability of construction materials used to develop beds, arbors, irrigation systems, etc. Multiple use for equipment among plant trialing and teaching programs allows sharing of maintenance overhead and purchase costs. Student exposure to multidisciplinary approaches can be enhanced by facilitating faculty involvement from other disciplines while assessing disease and pest resistance or marketing potential. Student involvement augments the typical research and extension activities associated with plant trialing and marketing programs, exemplifying the 3 -fold land-grant mission of teaching, research, and extension programs. 


\section{Literature cited}

Arnold, M.A. 1999. Landscape plants for Texas and environs. Stipes Publ., Champaign, Ill.

Arnold, M.A., M.W. Goyne, W.C. Welch, D.C. Wilkerson, and C.R. Hall. 1996. Facilitating container production of native Texas small trees for urban and suburban landscapes. Native Plant Soc. Texas News 14(3):8

Arnold, M.A., S.W. George, and J.M. Parsons. 1998a. Coordinated education and marketing assistance program (CEMAP): A case-study in cooperative industry / university state-wide plant trialing and promotion. Proc. $10^{\text {th }}$ Conf. of the Metropolitan Tree Improvement Alliance, St. Louis, Mo., 30 Sept.-1 Oct. 1998. 21 Apr. 2001. <http://fletcher.ces.state.nc.us/programs/nursery/metria/metrial0/ Arnold.htm>.

Arnold, M.A., W.A. Mackay, S.W. George, and J.M. Parsons. 1998b. CEMAP: A case study in statewide plant trials and promotion. Landscape Plant News 9(4):7-11.

Arnold, M.A. and G.V. McDonald. 1999. Accelerator ${ }^{\mathrm{TM}}$ containers alter plant growth and the root zone environment. J. Environ. Hort. 17:168-173.
Denny, G.C. and M.A. Arnold. 2000. Effects of substrate composition, K-IBA, and physiological maturity on rooting of Cotinus obovatus Raf. HortScience 35:550 (abstr.).

Goyne, M.W. 1998. Effects of alternative container media components on the growth of selected under-utilized small ornamental trees. MS thesis, Texas A\&M University, College Station.

Goyne, M.W., M.A. Arnold, W.C. Welch, D.C. Wilkerson, and C.R. Hall. 1997. Container production of under-utilized small trees for Texas' urban landscapes: A preliminary up-date. Landscape Plant News $8(1): 2-5$.

Hamilton, S.L. 1999. The roles of the University of Tennessee gardens in a public horticulture teaching program. HortTechnology 9:552-556.

Lewis, A.J. and J.M. Affolter. 1999. The state botanical garden of Georgia: A living laboratory for student education. HortTechnology 9:570-572.

Lineberger, R.D. and M.A. Arnold. 2001. Aggie horticulture plant picture pages. 21 April 2001. <http://horticulture.tamu.edu:7998/ornamentals/ search.html>.
Mackay, W.A., S. George, T. Davis, M. Arnold, D. Lineberger, J. Parsons, and L. Stein. 2000. Texas superstars: The coordinated educational marketing and assistance program in Texas. HortScience 35:565 (abstr.)

Mackay, W.A., S.W. George, T.D. Davis, M.A. Arnold, R.D. Lineberger, J.M. Parsons, L.A. Stein, and G.D. Grant. 2001. Texas Superstar ${ }^{\mathrm{TM}}$ and the Coordinated Educational and Marketing Assistance Program (CEMAP): How we operate. HortTechnology 11(3):389-391.

Morgan, CD., L.W. Barnes, M.A. Arnold, and G.V. McDonald. 2000. Disease tolerance and landscape performance of zinnia taxa in central Texas. Proc. S. Nurserymen's Assn. Res. Conf. 45:477-480.

Stimart, D.P. 1999. Development and integration of an instructional garden in education at the University of Wisconsin-Madison. HortTechnology 9:557-561.

VanDerZanden, A.M. and T. Cook. 1999. A multifunctional horticulture teaching garden at Oregon State University. HortTechnology 9:549-551. 